\title{
SURVEY AND TAXONOMY OF THE MAIN PESTS AND THEIR NATURAL ENEMIES ATTACKING CITRUS AND OLIVE TREES IN EGYPT AND MOROCCO IN COSTAL AREAS WITH SPECIAL KEYS TO THE PESTS AND THEIR NATURAL ENEMIES
}

Abd-Rabou, S. ${ }^{1}$ and M. Abbassi ${ }^{2}$

1 Plant Protection Research Institute, Agricultural Research Center, Dokki, Giza, Egypt.

2Laboratory of General Ecology and Applied Entomology, Faculty of Sciences, University of Moulay Ismail, Meknès, Morocco.

\begin{abstract}
The present work deals with the survey of main pests attacking citrus and olive in Egypt and Morocco. The results indicated that fourteen and seven species are the principal key pests attacking citrus and olive trees, respectively . Citrus pests associated with 18 parasitoids and 11 predators while olive pests associated with 11 parasitoids and 5 predators. The most important families of natural enemies were Aphelinidae,Encyrtidae,Eulophidae,Pteromalidae,Trichogrammatidae (parasitoids) an d Anthocoridae, Coccinellidae, Chrysopidae, Tetranychidae (Predators). Keys for the pests and their natural enemies were provided.
\end{abstract}

\section{INTRODUCTION}

The most important crops occurrence in Egypt and Morocco were citrus and olive. These pests caused a serious damage for the citrus and olive in Morocco and Egypt, respectively. Many of them can cause appreciable losses in quality and quantity of citrus and olive trees. Pests attacking citrus and olive were studied by Abbassi (1980), El-Hakim and El-Sayed (1985), Abdel-Rahman (1995). Abbassi (1996, 1999a,b), Abd-Rabou (,2001a, b ,2004a, b) and Abbassi $(2006,2007,2008)$.

The aim of this work is to study the survey of pests and thier natural enemies attacking citrus and olive trees in Egypt and Morocco.

\section{MATERIALS AND METHODS}

Sampling was carried out all over the year in different locations in Egypt and Morocco from 2007-2008 . Infested plant parts were placed in plastic bags and adult emergence was monitored. The materials was mounted and identified by the authors. The emerging adult parasitoids were transferred into vials of $70 \%$ ethanol. Identification of parasitoids made by slide mounted adults in Hoyers medium according to (Noyes,1982)..

The procedures of slide mounts as follows: Dried specimens are soaked in glacial acetic acid ( 7 drops) mixed with chloral phenol (5 drops) in small watch glasses.

a. After 48 hours specimens should be satisfactorily cleared.

b. The cleared specimens are then mounted in Hoyer's medium.

After drying for about two weeks under $40{ }^{\circ} \mathrm{C}$, the slide cover is ringed with a suitable sealer. Predators also was collected and identified. Identification of the parasitoids followed by the keys of Rosen and DeBach (1979), Temerak 
(1981), Hamon and Williams (1984), Noyes and Hayat (1994), Prinsloo (1996) and Hayat (1998).

\section{RESULTS AND DISCUSSION}

The result of this research indicated that there are diverse fauna of citrus and, olive in Egypt and Morocco . In a total of 20 pest species attacking citrus and olive in Egypt and Morocco, Aleyrodidae (3 species), Aphididae (3), Aphalaridae (1), Coccidae (1), Diaspididae( 5) , Gracillariidae (1), Melniopidae (1), Pseudococcidae(1), Tephritidae(1), Teteranchidae (1) and Yponomentidae (1). These species recorded here associated with 38 natural enemy species, Anthocoridae (1), Aphelinidae ( 10 species ), Aphidiidae (1), Chrysopidae (1) , Coccinellidae (10) , Encyrtidae (7), Eulophidae (3), Pteromalidae (1), Phytoseidae (1), Trichogrammatidae (3).

I. List of pests and their natural enemies of citrus in Morocco:

Fourteen species of pests [Aleyrodids (1), Aphidids (3), Coccids (1), Diaspidids (4), Gracillariids (1) , Melinopids (1), Pseudococcids (1) , Tetranychids (2)] attacking citrus trees in costal areas in Morocco which are attacked by 22 natural enemy species, Aphelinids (5), Aphidiids (1), Encyrtids (5), Eulophids (5), Coccinellids (6),

1. Pest : Aonidiella aurantii Maskell ( Homoptera : Diaspididae) Natural enemies :

Parasitoids: Aphytis melinus DeBach, Encarsia sp. (Hymenoptera: Aphelinidae) and Comperiella bifasciata Howard (Hymenoptera : Encyrtidae) Predators : Rhyzobius lophanthae (Blaisdell), Chilocorus bipustulatus (L.) (Coleoptera.: Coccinellidae).

2. Pest : Planococcus citri (Risso) ( Homoptera : Pseudococcidae)

Natural enemies :

Parasitoids: Leptomastix dactylopii Howard and Coccidoxenoides peregrinus (Timberlake) (Hymenoptera : Encyrtidae)

Predators : Cryptolaemus montrouzieri Mulsant (Coleoptera.: Coccinellidae)

3. Pest : Phyllocnistis citrella Stainton (Lepidoptera: Gracillariidae)

Natural enemies :

Parasitoids : Ageniaspis citricola Logvinovskaya (Hymenoptera: Encyrtidae), Cirrospilus ingenuus Gahan, Semielacher petiolatus (Girault), Citrostichus phyllocnistoides (Narayanan), Cirrospilus pictus Nees and Pnigalio sp. (Hymenoptera: Eulophidae),

Predators : $C$. bipistulatus

4. Pest : Icerya purchasi Maskell (Homoptera : Margaroidae)

Natural enemies :

Predators : Rodolia cardinalis (Mulsant) (Coleoptera: Coccinellidae).

5. Pest : cornuspis beckii (Newman) (Homoptera : Diaspididae).

Natural enemies :

Parasitoids : Aphytis lepidosaphes Compere (Hymenoptera : Aphelinidae)

Predators : $C$. bipistulatus

6. Pest : Parlatoria pergandii Comstock (Homoptera : Diaspididae).

Natural enemies :

Parasitoids : Aphytis hispanicus Mercet 
Predators : C. bipistulatus

7. Pest : Paralatoria ziziphi (Lucas) (Homoptera : Diaspididae).

Natural enemies :

Parasitoids : Aphytis sp. and Encarsia sp. (Hymenoptera : Aphelinidae) ;

8. Pest : Panonychus citri (Mc Gregor) (Acari: Tetranychidae)

Natural enemies :

Predators : Euseius sp. (Acari : Phytoseidae) and Stethorus sp. (Coleoptera:

Coccinellidae).

9. Pest : Tetranychus urticae (Koch) (Acari: Tetranychidae)

Natural enemies :

Predators : Euseius sp. And Sthetorus sp.

10. Pest : Toxoptera aurantii (Boyer de Fonscolombe) (Homoptera:

Aphididae)

Natural enemies :

Parasitoids : Aphidius sp. (Hymenoptera: Aphidiidae)

Predators : Coccinella transversalis Fabricius (Coleoptera: Coccinellidae).

11. Pest : Myzus persicae (Sulzer) (Homoptera: Aphididae)

Natural enemies :

Parasitoids : Aphidius sp.

Predators : $C$. transversalis.

12. Pest : Aphis spiraecola Patch (Homoptera: Aphididae)

Natural enemies :

Parasitoids : Aphidius sp.

Predators : $C$. transversalis

13. Pest : Coccus hesperidum Linnaeus (Homoptera: Coccidae)

Natural enemies :

Parasitoids : Metaphycus sp. ( Hymenoptera: Encyrtidae)

14. Pest : Aleurothrixus floccosus Maskell (Homoptera: Aleyrodidae)

Natural enemies :

Parasitoids : Cales noacki Howard (Hymenoptera : Aphelinidae)

Key of pests attacking citrus in Morocco

1. It comprises two regions, cephalothorax and abdomen and four legs.....2

- It comprises three regions, head, thorax and abdomen and three legs......3

2. Two pairs of para-anal setae, tibia I with 1 smooth solenidion, Hysterosoma with clunal setae (h1) similar in length to outer sacral setae $(\mathrm{f} 2)$ f 2 near onethird as long as inner sacral

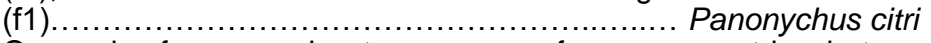

One pair of para-anal setae, summer form green; striae between third (e1) and fourth dorsomedian setae (f1) often with semi-oblong or rounded lobes, which are wider than tall; tibia I with only 10 setae; male: aedeagus with acute anterior angulation, dorsum of knob of aedeagus rounded................................ Tetranychus urticae

3. Wings covered with scales, adults are small, with a wingspan of 0.16 in (4 $\mathrm{mm}$ ) and a length of 0.08 in $(2 \mathrm{~mm})$ at rest. The forewing is white with silvery reflections, black and tan markings, and a small apical black spot. Full-grown larvae $(0.12 \mathrm{in}$, or $3 \mathrm{~mm})$ are flattened and translucent green with atrophied prolegs and legs.... Phyllocnistis citrella Wings not covered with scales, though they may be hairy, mouth-parts tube-like, adapted for piercing and sucking.............................

4. Tarsi 1 segmented with a single claw. .5 
Tarsi 2 segmented with two claws 11 Abdominal spiracles present, anal ring simple with no pores or setae, antennae 1-3 segmented.... Icerya purchasi Abdominal spiracle absent ...6

6. With an anal plate or plates covering or lying over the anal opening, dorsum with a pair of triangular or subtriangular plates which form an operculum covering the anal opening and situated at anterior end of a well-developed anal cleft, dorsal setae cylindrical with pointed apex

Coccus hesperidum

Without an anal plate or plates lying over the anal opening .7 Posterior segments of abdomen fused into pygidium or a pygidium-like area, body usually covered with a shield-like scale which is easily separable from body, anal ring simple without setae ................... 8 Posterior segments of abdomen not fused into pygidium, body not covered with a shield-like, anal ring simple without setae, multilocular disc pores scarce behind anterior coxae and posterior spiracles, these pores on the posterior portion of abdominal segments usually arranged in a continuous double row, with more ventral tubular ducts on head 12 (619) and on prothorax 24 (16-32) Planococcus citri

8. Pygidium of adult female without plates, with gland spines only, groups of privulvar pores present, with submarginal round bosses on the first two and fourth abdominal segments, one boss on each side of a segment ................................................. Lepidosaphes beckii

Pygidium of adult female usually with plates, with or without gland spines only.... ..9

9. Macroducts of the one-barred type, disposed mostly in the glandiferous marginal or submarginal farrows or crypts of the different pygidial areas, cephalothotacic cuticle thickened, thoracic laterally turned down and encircling the pygidium, external plates are present on segment VI............................................... Aonidiella aurantii

lacroducts of the two-barred type, disposed on isolated elements or in gular order on the different pygidial areas...........................10

10. Eye spot greatly enlarged, appearing as car-like lobes, shield black.................................................Paralatoria ziziphi

Eye spot either spur like or lacking, shield never black, Lobe 3 and lobe 4 separated by four lateral plates....................... Parlatoria pergandii

11. Antennae with 3-7 segments, presence of the submarginal fold at the caudal area, it is probably an extended pair of longitudinal folds, which is usually present in combination with a rhachis, dorsal surface covered with cotton-like secretions Aleurothrixus floccosus

Antennae usually 6 segmented....

Frontal tubercles very developed. Siphunculi more or less swollen. Body brown or green Frontal tubercles converging, inward on mesal side, spinulosa. Third antennal segment of aptera without rhinaria. Siphunculi is much longer than cuda, cylindrical or swollen at apical third. Cauda some what constricted at or near middle and acuminate at apex, with three lateral hairs. Abdomen with a large more or less soild black patch. Body green, light pink or pale.......................... Myzus persicae Frontal tubercles present bur not very developed. Siphunculi cylindrical,never swollen....................................................13

13 With a stridulating mechanism, body brown or black, third antennal segment of alate pale except at the very apex and having 2-8 rhinariae, arranged in a single row and extending to the whole length, fourth segment without rhinaria. Media of forewing once branched Toxoptera aurantii 
Without a stridulating mechanism, body greenish yellow or grey, fourth antennal segment of alate somewhat with 0-4 rhinariae, cauda with more than 3 lateral hairs, body usually living within curl leaves............................................. Aphis spiraecola

\section{Key of parasitoids associated with pests attacking citrus in Morocco}

1. Antennae not elbowed, head transverse, as wide as wider than thorax at tegulae, occiput marginal. Antennae with variable number of segments

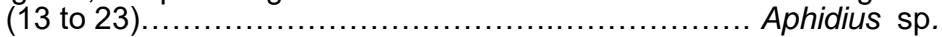

Antennae usually elbowed, number of antennal segments, fore wing with five or fewer cells. ..3

Mesopleuron immpressed and with a femoral groove................... 7 Forewing shortened, not extended to apex of metasoma, funicle cylindrical, mesosoma and metasoma dorsally matt, without metallic reflections, flagellumwith at least some sements white...Metaphycus sp.

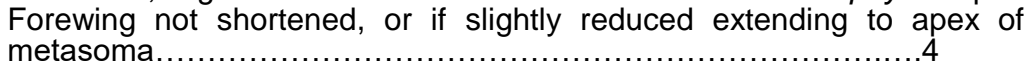
metasoma. Scape not more than 3 times as long as broad, forewing with two longitudinal infuscate rays, clava with apex transverses truncate, Mesoscutum, except sides of disc, dark metallic -green with a median longitudinal cuperous band extending over entire length of disk, lateral ocelli separated from each other by about twice their own diameter, median longitudinal dark area on frontovertex wider than each of the two lateral white band, tibial spur of middle leg distinctly longer than basitarsus ..Comperiella bifasciata

Scape more than 3 times as long as broad ...............................5

5. Clava 1-segmented, scutellum and mesoscutum with deep longitudinal striate sculpture, funicle with first 2 segments shoter than third ...

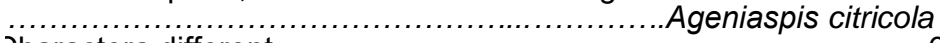

Zharactera different............................................................

6. Funicle with all segments longer than borad, scutellum and mesoscutum shiny, with similar shallow reticulate sculpture... Leptomastix dactylopii Funicle not with all segments longer than borad, scutellum and mesoscutum not strongly convex, frequently metallic but in matt then sculpture not finely striate, submarginl vein with strong subapical expansion ............................... Coccidoxenoides peregrinus

Tarsi four-segmented ........ 8

Tarsi five-segmented 12

8. Funicle that is 3-4 segmented, ...

Funicle that is 2 -segmented....

9. Adult black, one translucent patch on the abdomen, compound eyes and ocelli red, antenna yellow, funicle elongate 3 -segments, club elongate 3segments with setae. All legs yellow, tarsi 4-segments. Male smaller than female.... . Citrostichus phyllocnistoides

Adult mainly metallic-green or green with white to brown coloured markings on scape, and legs. Female funicle 4- and club 2-segmented (rarely funicle and club both 3 -segmented)................ Pnigalio sp.

10. Adults are 1 to $2 \mathrm{~mm}$ long, the female is brown with a yellow abdomen and the male's abdomen is brown at the tip Funicle with 2-3 segments,.

Funicle that is 2-segmented Semielacher petiolatus Propodeum smooth, lightly sculptured and sculpturing on scutellum incised. Host rane wide and variable .................... Cirrospilus pictus Propodeum distinct, strong sculptured, gaster with 3 to 5 complete transverse dark strips................................ Cirrospilus ingenuus

12. Antennae 7-9 segmented, fore wing without linea calva .... Encarsia sp. 
Antennae 4-6 segmented, fore wing generally with linea calva 13

13. Propodeal crenulae large and overlapping, club 3.4 to fully 4 times as long as wide, fully...................................Aphytis melinus Propodeal crenulae (large or small) non-overlapping................14

14. Mesoscutum 13 setea, , 4 times as long as metanotum

........................................... Aphytis hispanicus Mesoscutum 12 setea, , 4.5 times as long as metanotum.

Aphytis lepidosaphes

\begin{abstract}
Key of predators associated with pests attacking citrus in Morocco
1. Four pairs of legs, dorsal shield smooth, with setae and movable digit with teeth, predators of mites ......................... Euseius spp. Three pairs of legs, tarsi appearing 3-3-3, but actually 4-4-4, head often concealed by pronotum, antennae short with a 3 - to 6 -segmented club...2

2. Ladybirds are medium to large size ladybirds $(3-12 \mathrm{~mm})$ that with smooth ......................................................

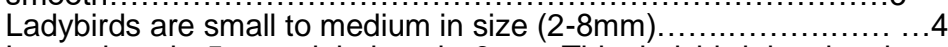

3. Larva length $5 \mathrm{~mm}$, adult length $3 \mathrm{~mm}$ This ladybird is also known as mealybug destroyer....................... Cryptolaemus montrouzieri Larva length $7 \mathrm{~mm}$, adult length $5-6 \mathrm{~mm}$ Transverse ladybirds are common in Brisbane. They active during the day and both adults and larvae are predators of soft-bodied insects such as aphids. Both adults and larvae can be found on the same plants. .... Coccinella transversalis

4. Their body is covered with short hairs............ Rhyzobius lophanthae

- Their body is covered with different .............................

5. Their body is in round helmet shape, The ladybird was bright orange in colour with dark edges on the wing-cover base...Chilocorus bipustulatus Their body small or very small.........................................6

6. Adults are very small, densely pubescent, red and black lady beetles, about 2.5-4 mm (1/16-3/16 inch) long................. Rodolia cardinalis Adults are tiny, $1.5 \mathrm{~mm}$ long, dark brown to black, oval beetles with brownish yellow antennae, mouthparts and legs............ Stethorus sp.
\end{abstract}

\title{
II. List of pests and their natural enemies of olive in costal areas in Egypt:
}

Seven species of pests [Aleyrodids (2), Aphalarids (1), Coccids (1), Diaspidids (1), Yponomeutids (1), Tephritids (1)] attacking olive trees in costal areas in Egypt which are attacked by 17 natural enemy species [Anthocorids (1), Aphelinids (5), Chrysopids (1), Coccinellids (4), Encyrtids (3), Pteromalids (1), and Trichogrammatids (2)].

1. Pest : The olive whitefly, Aleurolobus olivinus (Silvestri) (Homoptera:

Aleyrodidae)

Natural enemies :

Parasitoids : None

Predators : None

2. Pest : The pomegranate whitefly, Siphoninus phillyreae (Haliday)

(Homoptera: Aleyrodidae)

Natural enemies :

Parasitoids : Encarsia inaron (Walker) (Hymenoptera : Aphelinidae)

Predators : None

3. Pest : The olive fruit fly (Bactrocera oleae (Gmelin) (Diptera: Tephritidae) 
J. Agric. Sci. Mansoura Univ., 34 (10), October, 2009

Natural enemies :

Parasitoids : None

Predators : None

4. Pest : Euphyllura straminea Log. (Homoptera: Aphalaridae)

Natural enemies :

Parasitoids : None

Predators : None

5. Pest : Parlatoria oleae Colvée (Homoptera : Diaspididae).

Natural enemies :

Parasitoids : Aphytis paramaculicornis DeBach and Rosen, A. chrysomphali

Mercet and Encarsia aurantii (Howard) (Hymenoptera : Aphelinidae)

Predators : None

6. Pest : Prays oleae (Bern) (Lepidoptera: Yponomeutidae)

Natural enemies :

Parasitoids : Trichogramma cordubensis Vargas and Cabello and

Trichogramma cacoeciae Marchal (Hymenoptera : Trichogrammatidae )

Predators : Chrysoperla carnea (Stephens) (Neuroptera: Chrysopidae)

7. Pest : Coccus hesperidum L. (Homoptera: Coccidae)

Natural enemies :

Parasitoids :

Diversinervus elegans Silvestri, Metaphycus flavus (Howard) (Hymenoptera:

Encyrtidae) and Marietta leopardina Motschulsky (Hymenoptera:

Aphelinidae)

Predators :

C. bipustulatus, Scymnus syriacus Marseul and Exochomus flavipes

(Thunberg) (Coleoptera: Coccinellidae) .

8. Pest : The Medditearian black scale, Saissetia oleae ( Olivier)

(Homoptera: Coccidae)

Natural enemies :

Parasitoids :

Baeoanusia sp. , Diversinervus elegans Silvestri, Metaphycus flavus (Howard), M. zebratus Mercet $M$. helvolus, Microterys flavus, Parechthrodruinus coccidiphagus (Hymenoptera: Encyrtidae), Scutellista caerulea (Fonscolombe) ((Hymenoptera: Pteromalidae) and Marietta leopardina Motschulsky (Hymenoptera : Aphelinidae)

\section{Predators :}

C. bipustulatus, C. carnea, Coccinella undecimpunctata Linnaeus, Scymnus syriacus Marseul and Exochomus flavipes (Thunberg) (Coleoptera: Coccinellidae) and Orius sp. (Hemiptera: Anthocoridae).

\section{Key of pests attacking olive in Egypt}

1. Insects with only two wings (one pair), scutum (dorsal area of thorax) without lateral yellow vittae ............................Bactrocera oleae

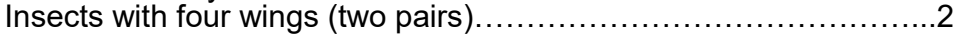

2. Wings not covered with scales, though they may be hairy..... ...3 Wings covered with scales, Fore wings grey with silvery tone and small scattered dark spots. Hind wings are of uniform grey with frayed margins. 
3.

Grey scales with a silvery tones cover the body and legs...................................................... Prays oleae

Tarsi 1 segmented with a single claw...................................

Tarsi 2 segmented with two claws ...................................6

4. With an anal plate or plates covering or lying over the anal opening, Dorsum with a pair of triangular or subtriangular plates which form an operculum covering the anal opening and situated at anterior end of a well-developed anal cleft, dorsal setae cylindrical with pointed apex ........ 5

Without an anal plate or plates lying over the anal opening. Posterior segments of abdomen fused into pygidium or a pygidium-like area, body usually covered with a shield-like scale which is easily separable from body, anal ring simple without setae -Pygidium of adult female without plates, with gland spines only, groups of privulvar pores present, with submarginal round bosses on the first two and fourth abdominal segments, one boss on each side of a segment

5. Dorsal tubular ducts present in a very small number on the marginal area only, ventral tubular ducts few, on thorax only............................................ Coccus hesperidum

Dorsal tubular ducts absent, ventral tubular ducts present and numerous, dorsal setae conical, vulvar setae 4 or 5 on each side................................................. Saissetia oleae

6. Antennae more than 8 segmented, adults are pale green to tan in color mixed with light brown and tiny, black Antennae with $3-7$ segments ........................................................ 7

7. Dorsal disc covered with siphon-like glands, body pale, the dorsal surface has 40 to 50 long glassy tubercles

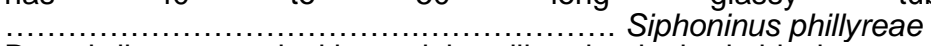
Dorsal disc covered without siphon-like glands, body black, resembles a flat pellet stuck to the leaf. Aleurolobus olivinus

\section{Key of Parasitoids associated with pests attacking olive in Egypt \\ Tarsi 3- segmented.}

1

-

arsi 4 or 5 segmented

lale antennal setae are longer.................... Trichogramma ordubensis

lale antennal setae are shorter

Trichogramma cacoeciae

Mesophleuron large and without a femoral groove ...................... 9

Mesophleuron immpressed, and with a femoral groove.................. 4

Gaster distinctly constricted at its Junction with propodeum; female antenna with 9; scutellum very long, at least twice as long as mesoscutum; extending well over the gaster................................................ Scutellista caerulea

Gaster subsessile, broadly attached with the propodeum................. 5

Antennae $7-9$ segmented, fore wing without linea calva ................. 6

Antennae 4-6 segmented, fore wing generally with linea calva .............7 Wings infuscated below the marginal and /or stigmal veins, fore wing narrow, third valvula 0.56 times as long as valvifer......................................... Encarsia aurantii Wings hyaline,pedicel shorter than F1. F1 subequal in length to F2, F3 and F4 individually.................................. Encarsia inaron Propodeum short, without crenulea, antennal scape with the band short, extending cauded from about middle of ventral margin Propodeum long, bearing marginal crenulea ............................ Occiput with a fuscous to black bar on each side of foramen, the mouth
margin and/or malar sulcus sometimes fuscous, clava usually about $3 x$ as 


\begin{tabular}{|c|c|}
\hline & species \\
\hline & $\begin{array}{l}\text { cciput without such bars on sides of foramen; mouth margin and malar } \\
\text { lcus usually not fuscous, clava more than } 3 x \text { as long as broad. } \\
\text { Iniparental species )........................ Aphytis chrysomphali }\end{array}$ \\
\hline & 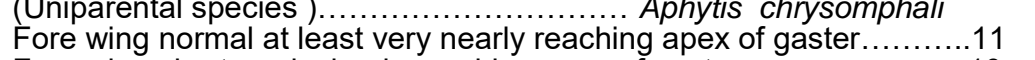 \\
\hline & re wing shortened, clearly reaching apex of gaster.......... \\
\hline & 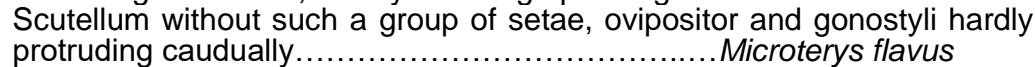 \\
\hline & $\begin{array}{l}\text { Scutellum without a subapical group of dark coarse setae arranged in a } \\
\text { more or less compact bundle, mesoscutum with a distinct transverse } \\
\text { depression, body yellow, sides of propodeum, and mesopleura posteriorly } \\
\text { more or less dark metallic.............. Diversinervus elegans }\end{array}$ \\
\hline 11 & 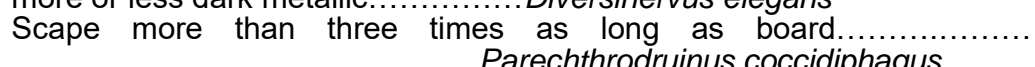 \\
\hline & cape not more than three times as lor \\
\hline & 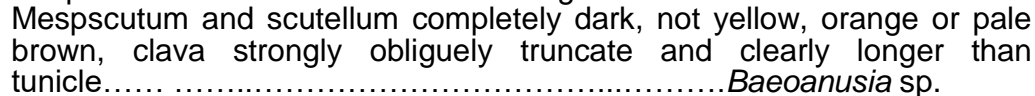 \\
\hline & Mespscutum or scutellum or both at least partly yell \\
\hline 13 & cape more \\
\hline & Maxillary palpi 2-3segmented. \\
\hline 14 & $\begin{array}{l}\text { Maxillary palpi } 3 \text {-segmental, legs without annular darkish spots on tibiae, } \\
\text { antennal scape about } 3.5 \text { times as long as the greatest } \\
\text { width. }\end{array}$ \\
\hline & 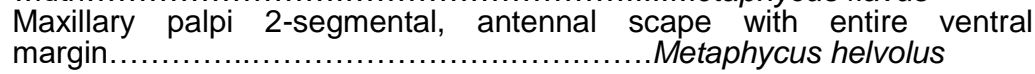 \\
\hline & f predators associated with pests attacking olive in Egypt \\
\hline 1. & $\begin{array}{l}\text { Four membranous wings, with the forewings and hindwings about the } \\
\text { same size, and with many veins. Adult green lacewings are pale green, } \\
\text { about } 12-20 \mathrm{~mm} \text { long, with long antennae and bright, golden eyes. They } \\
\text { have large, transparent, pale green wings and a delicate } \\
\text { body............................................................... }\end{array}$ \\
\hline & ys differe \\
\hline 2. & $\begin{array}{l}\text { Wings not covered with scales, th } \\
\text { (1/8 inch) black bugs with white } n \\
\text { (hemelytra), resulting in a band-l } \\
\text { wings are at rest.............................. }\end{array}$ \\
\hline & 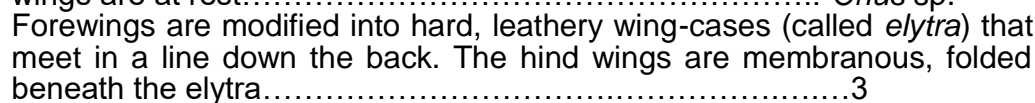 \\
\hline 3. & $\begin{array}{l}\text { Postcoxal line on first abdominal sternum curved forward at apex } \\
\text { complete ........................................ Exochomus flavipes }\end{array}$ \\
\hline & \\
\hline 4 & $\begin{array}{l}\text { Antennae short, dorsal surface densely pubescent ........Scymnus syriacus } \\
\text { Antennae long }\end{array}$ \\
\hline & 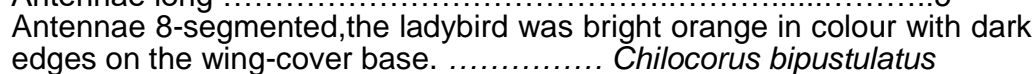 \\
\hline & \\
\hline
\end{tabular}

\section{ACKNOLEDGEMENTS}

This work was sponsored by Egyptian- Moroccoian Science and Technology in cooperation with Plant Protection Research Institute, Agricultural Research, Egypt and Faculty of Sciences, University of Moulay Ismail, Meknès, Morocco under project entitled "Augmentation and 
conversation of natural enemies of pests attacking crops in costal and wetland areas".

\section{REFERENCES}

Abbassi, M. (1980): Recherche sur deux Homopteres fixes des Citrus, Aonidiella aurantii (Mask.) et Aleurothrixus floccosus ( Mask.) ; les Cahiers de la Recherche Agronomique, 35 :168pp.

Abbassi, M. (1996): Biologie et ecologie de la mineuse des feuilles de Citrus, Phyllocnistis citrella (Stainton), (Lepidoptera: Gracillariidae) au Maroc.C.R. au seminaire international sur la mineuse des agrumes, Blida, Algerie, 35 :168pp.

Abbassi, M. (2006): Ravageurs sporadiques sur agrumes: la cochenille farineuse, la cochenille australienne et la cochenille plate. Agriculture du Maghreb, $16: 56-57$.

Abbassi, M. (2007): Principaux ravageurs sur fleurs et sur jeunes fruits noues de agrumes. Agriculture du Maghreb, $20: 90-94$.

Abbassi, M. (2008): Note au sujet de la ravageurs consideres comme secondaires au Maroc et aspects pratiques de lutte. Symposium Mediterraneen sur la Protection Phytosanitairae des Agrumes, AMPP Institut Agronomique et Vétérinaire Hassan II Rabat, 2008 : 253-258.

Abdel-Rahman, A G. (1995): Seasonal abundance of some pests attacking olives and their control under El-Qasr conditions, Matrouh Governorate.Annals of Agricultural Science, Moshtohor. 33(4): 15531564.

Abd-Rabou, S. (1999a): Parasitoids attacking the Egyptian species of armored scale insects (Homoptera : Diaspipidae). Egypt. J. Agric. Res., 77(3): 1113-1129.

Abd-Rabou, S. (1999b): Parasitoids attacking the Mediterranean black scale, Saissetia oleae (Hemiptera: Coccidae) in Egypt. Entomologica Bari, 33: 169-172.

Abd-Rabou, S. (2001a): A survey of parasitoids associated with the hemispherical scale, Saissetia coffeae (Walker) (Hemiptera : Coccidae) in North-west Coastal area of Egypt. Bull. Fac. Agric. Cairo, Univ. Special Edition, 1-5.

Abd-Rabou, S. (2001b): The effect of augementitive releases of indigenous parasitoids on populations of Parlatoria oleae (Clovee')(Homoptera : Coccidea) in olive groves in Egypt. Boll. Zool. Agr. Bachic, 33(3): 473-481.

Abd-Rabou, S. (2004a): The role of augmentative releases of indigenous parasitoid Metaphycus lounsburyi (Hymenoptera: Encyrtidae) in inhancing the biological control of Saissetia oleae (Hemiptera: Coccidae) on olive in Egypt. Archives of Phytopathology and Plant Protection, 37(3): 233-237.

Abd-Rabou, S. (2004b): Augmentative releases of indigenous parasitoids of the Mediterranean Black Scale Saissetia oleae (Oliver) (Hemiptera : Coccidae) on olive in Egypt. Shashpa, 11(1):51-56 
El-Hakim, A.M. and El-Sayed, S. (1985): Studies on the infestation of olive fruits with the olive fruit fly Dacus oleae Gmel, in Egypt (Tephrytidae: Diptera). Bulletin de la Société Entomologique d'Egypte. (64): 221-225.

Hamon, A. B. and Williams, M. C. (1984): The soft scale insects of Florida (Hom.: Coccoidea : Coccidae). Arthropoda of Florida and Neighbouring land ares, $11194 \mathrm{pp}$.

Hayat, M. (1998): Aphelinidae of India (Hymenoptera: Chalcidoidea): A Taxonomic Revision. Memoirs on Entomology, International, 13: viii + $416 \mathrm{pp}$.

Noyes, J. S. (1982): Collecting and preserving chalcidid wasps (Hymenoptera : Chalcidoidea). Journal of Natural History, 16: 315-334.

Noyes, J. S. and Hayat, M. (1994): Oriental mealybug parasitoids of the Anagyrini (Hymenoptera: Encyrtidae). C.A.B. International, Wallingford.

Prinsloo, G.L. (1996): The genus Comperiella (Hymenoptera : Encyrtidae) in southern Africa: parasitoids of armoured scale insects ( Homoptera : Diaspididae). African Entomology, 4(2): 153-160.

Rosen, D. and DeBach, P. (1979): Species of Aphytis of the world (Hymenoptera: Aphelinidae). Dr. W. Junk KV Publisher, The Hague.

Temerak, S. A. (1981): Histroical records of parasitoids in Egypt (1905-1981). Techniacl Bulletin No. 1, Assiut Univ. Egypt, pp 80.

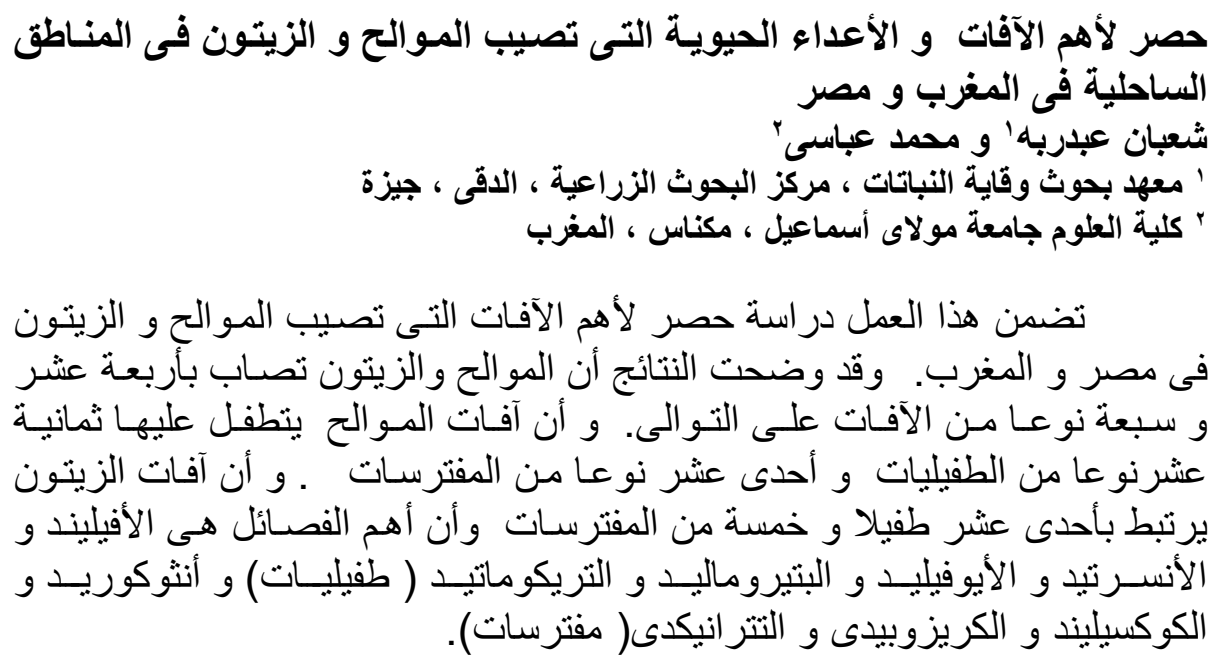

